\title{
An Unusual Case of Thyroid Papillary Carcinoma with Solitary Cerebral Metastasis Presenting with Neurological Symptoms
}

\author{
Soliter Beyin Metastazı ve Nörolojik Semptomla Beliren Tiroid Papiller \\ Karsinomu: Olgu Sunumu
}

Indranil CHAKRABARTI, Amita GIRI, Kaushik MAJUMDAR, Anuradha DE

Department of Pathology, North Bengal Medical College, WEST BENGAL, INDIA

\section{ABSTRACT}

Papillary carcinoma of the thyroid is well known for metastasis to regional lymph nodes resulting in early detection and overall favorable prognosis. Solitary metastasis of papillary carcinoma of the thyroid in the cerebrum is extremely rare with only a few cases reported in the literature. Here, we report an unusual case of a 40-year-old female patient who presented with neurological symptoms and a radiological diagnosis of meningioma was made. Subsequent histopathology from the resected brain tumor revealed a solitary cerebral metastasis from papillary carcinoma of the thyroid. There was no involvement of regional lymph nodes and the radiological findings were indicative of a primary brain tumor.

Key Words: Brain, Papillary thyroid carcinoma, Metastasis

\section{ÖZ}

Tiroid papiller karsinomu bölgesel lenf düğümlerine metastaz yaparak erken tanı konmasına neden olur ve iyi prognozludur. Tiroid papiller karsinomunun soliter beyin metastazi nadirdir ve literatürde yayınlanmış çok az sayıda olgu vardır. Burada, nörolojik semptomlar ile başvuran, radyolojik olarak meningiom tanısı alan 40 yaşında bir kadın hasta sunulmaktadır. Tümör rezeksiyon materyalinin histopatolojik incelemesi sonucu tiroid papiller karsinomunun soliter beyin metastazı tanısına ulaşılmıştır. Olguda bölgesel lenf dügüumü metastazı yoktur ve radyolojik olarak primer beyin tümörü olarak değerlendirilmiştir.

Anahtar Sözcükler: Beyin, Tiroid papiller karsinomu, Metastaz

\section{INTRODUCTION}

Papillary carcinoma of the thyroid is the most common type of thyroid tumor being slightly more common in women. In general, papillary carcinoma of the thyroid appears to have a good prognosis with involvement of regional lymph nodes. Cases of distant metastasis of papillary carcinoma of the thyroid have been reported mostly to the lung, bone and liver. Evidently, the prognosis worsens with the presence of a distant metastasis. Solitary metastasis to cerebrum is extremely uncommon with only a few cases reported in the literature. In various studies undertaken, a solitary cerebral metastasis has been detected in only $0.4 \%$ to $1.2 \%$ of the rare subgroup of papillary carcinomas in which distant metastasis occurs and the brain appears to be as susceptible as lungs or bones to be the first site of a distant metastasis (1).

Received : 04.03.2009

Accepted : 29.04.2009

\section{CASE REPORT}

A 40-year-old woman presented to the outpatients department with evidence of headache, disorientation, drowsiness, vomiting and weakness in the left side of the body for the last two weeks. She also suffered from two episodes of convulsions during this period. Physical examination revealed a small, $2 \mathrm{~cm}$ mass on the right side of the neck which moved vertically on swallowing. The patient was unaware of her neck lesion. An urgent CT scan was advised which revealed a mass $5 \times 3 \mathrm{~cm}$ on the right cerebral hemisphere in the frontal region with intimate attachment to the duramater (Figure 1). A radiological suggestion of meningioma was made. Fine needle aspiration cytology (FNAC) was done from the neck mass. Hematological and biochemical examinations, including thyroid function test and chest X-ray were performed.

Correspondence: Indranil CHAKRABARTI

Department of Pathology, North Bengal Medical College,

WEST BENGAL, INDIA

E-mail: drinch@rediffmail.com Phone: +9103324161597 


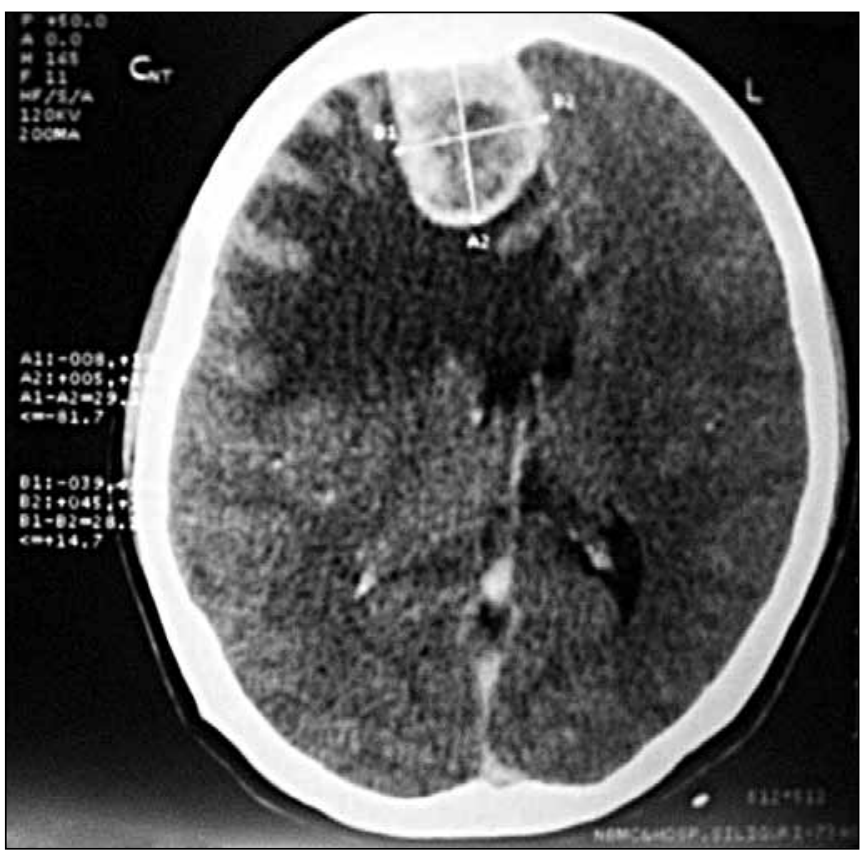

Figure 1: CT scan report showing a right frontal lobe space occupying lesion (SOL) with attachment to the duramater.

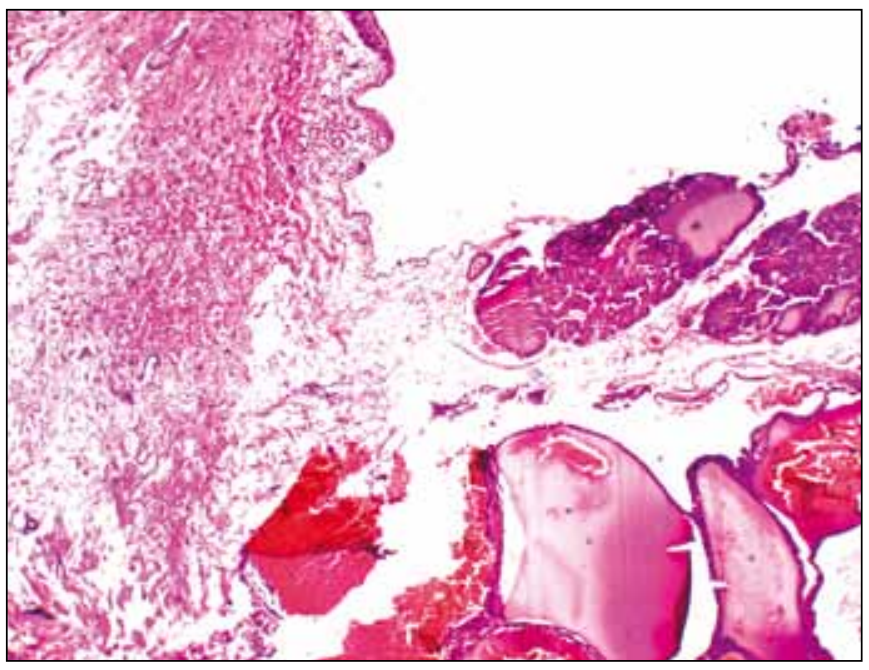

Figure 2: Microphotograph showing brain tissue (left) with metastatic deposits of papillary carcinoma of thyroid (right) (H\&E; x100).

The space-occupying lesion in the brain was excised and sent to the histopathology laboratory.

The hematological and biochemical parameters as well as the chest X-ray did not reveal any abnormal findings. The cytology smears obtained by fine needle aspiration done from the neck swelling showed cytological features of papillary carcinoma of the thyroid.
Gross examination of the resected brain tumor revealed a $6 \times 4 \times 3 \mathrm{~cm}$ mass. The cut section showed partly solid and cystic areas. The cystic areas were chocolate brown in color containing colloid-like material and small papillary projections. The surrounding brain tissue could be identified grossly.

Microscopy showed presence of papillae lined by follicular cells with Orphan Annie eye nuclei showing characteristic overlapping. There were few cells with intranuclear inclusions and grooves. Some colloid filled follicles with evidence of scalloping and abortive follicles were also seen (Figures 2,3). The surrounding brain parenchyma showed evidence of reactive gliosis.

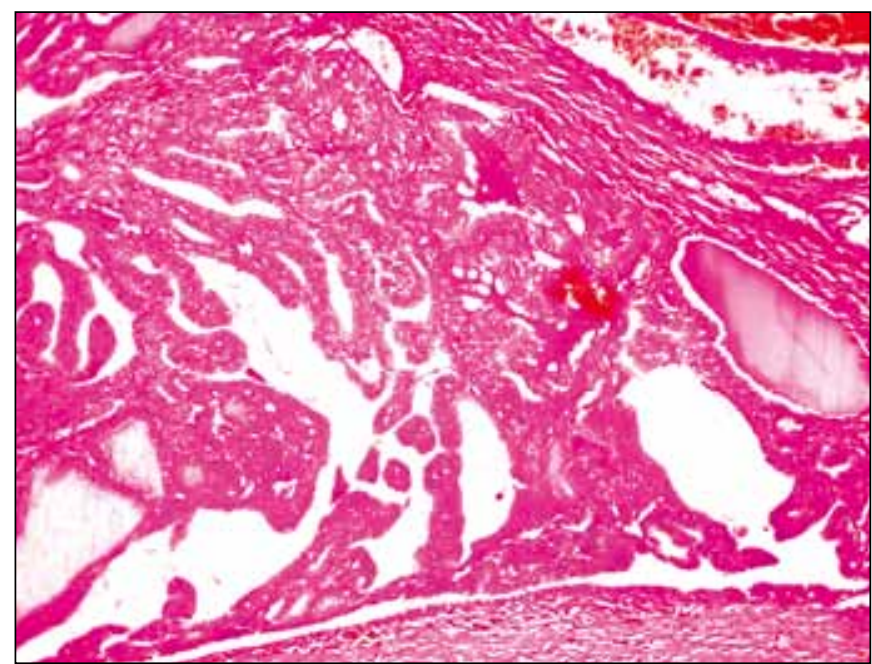

Figure 3: Microphotograph showing metastatic deposits of papillary carcinoma of thyroid at a higher magnification. (H\&E; x400).

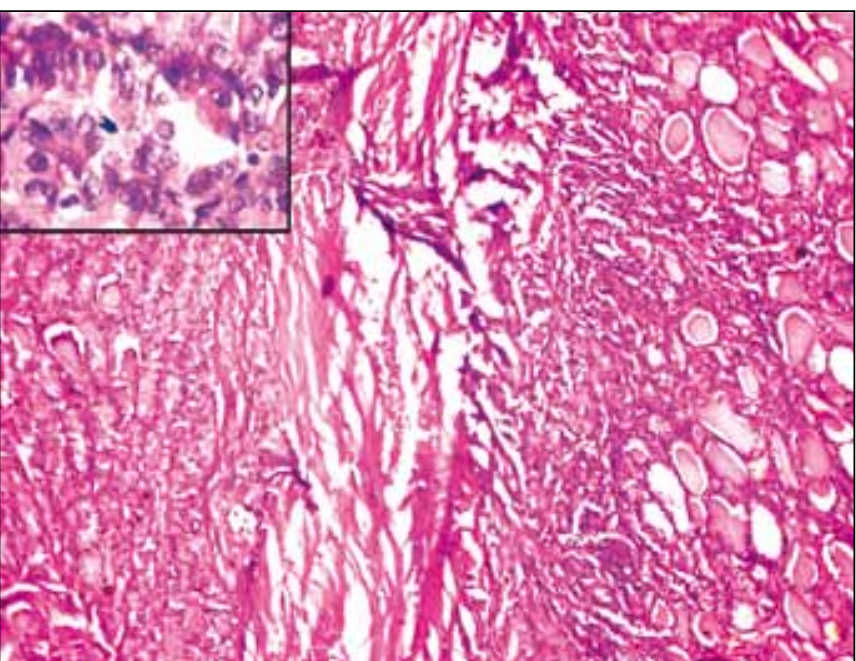

Figure 4: Microphotograph showing papillary carcinoma of total thyroidectomy specimen (left) separated from normal thyroid by a capsule; (H\&E; x400). Inset shows optically clear nuclei with nuclear grooves (arrowhead). 
A histopathological diagnosis of metastatic deposit of papillary carcinoma of the thyroid in the brain tissue was made based on the gross and microscopic findings.

Neurological symptoms improved after surgery.

Total thyroidectomy was performed 3 weeks after the craniotomy and the findings were confirmatory of papillary carcinoma of the thyroid (Figure 4). No other site of metastasis could be detected.

\section{DISCUSSION}

Distant metastases of papillary carcinoma of the thyroid are very rare and signify a poor overall prognosis if present. Solitary metastasis to the brain is even rarer with only a few reported cases in the literature. In a series, McConahey et al. reviewed 859 patients of papillary carcinoma of the thyroid and $11(1.3 \%)$ were identified as having cerebral metastases (2). The study conducted by Hoie et al. revealed that 91 of 731 patients with papillary carcinoma of the thyroid had distant metastases and only nine of these patients (1.2\%) had brain metastases (3). On the other hand, secondaries in brain are mainly from primary malignancies in the lungs, breast, melanomas, bones and genitourinary tract and very rarely from the thyroid. The present case presented with neurological symptoms initially with no complaints or symptoms relating to the primary lesion which she was completely unaware of. Michie HR et al described a case of occult primary papillary carcinoma of the thyroid in which the patient presented with headache and visual impairment (4). In our case, the radiological findings suggested a diagnosis of meningioma because of its location and radiological findings. Likewise, in a patient described by Ohta $\mathrm{Y}$ et al the radiological suspicion was that of a cavernous angioma, suggesting a strong clinical suspicion is warranted to clinch a diagnosis (5).

To conclude, we report a very rare case of papillary carcinoma of thyroid with solitary cerebral metastasis without involvement of regional lymph nodes in which the patient presented with neurological symptoms and the radiological findings were indicative of a primary brain tumor.

\section{REFERENCES}

1. Ota T, Bando Y, Hirai M, Tanaka N, Takabatake Y, Kasahara Y, Fujisawa M: Papillary carcinoma of the thyroid with distant metastases to the cerebrum: a case report. Jpn J Clin Oncol 2001, 31: 112-115

2. McConahey WM, Hay ID, Woolner LB, van Heerden JA, Taylor WF: Papillary thyroid cancer treated at the Mayo Clinic, 1946 through 1970: initial manifestations, pathologic findings, therapy, and outcome. Mayo Clin Proc 1986, 61:978-996

3. Hoie J, Stenwig AE, Kullmann G, Lindegaard M: Distant metastases in papillary thyroid cancer. A review of 91 patients. Cancer 1988, 61:1-6

4. Michie HR, O'Bryan-Tear CG, Marsh H, Glazer G: Cerebral metastases from occult papillary carcinoma of the thyroid. Br J Surg 1987, 74:647

5. Ohta Y, Chong JM: Solitary brain metastasis of thyroid papillary carcinoma mimicking a cavernous angioma by MRI. No Shinkei Geka 2009, 37:467-472 